\title{
A new species of Geniostoma (Loganiaceae) from Lord Howe Island
}

\author{
Barry J. Conn
}

\begin{abstract}
Conn, Barry J. (National Herbarium of New South Wales, Royal Botanic Gardens, Mrs Macquaries Road, Sydney, NSW, Australia 2000). 1993. A new species of Geniostoma (Loganiaceae) from Lord Howe Island. Telopea 5(2): 301-304. Geniostoma huttonii is described for the first time.
\end{abstract}

\section{Introduction}

Exploration of the flora of Lord Howe Island by Mr Ian Hutton has revealed the presence of an undescribed species of Geniostoma. This species is here described for the first time. Terminology and presentation follows that used by Conn (1980).

\section{Geniostoma huttonii Conn, sp. nov.}

Frutex subscandens ad $1 \mathrm{~m}$ altus. Ramuli teretes, internodiis supremis complanatis, glabri; stipulae depresse deltoideae ad annularibus, $1-1.4 \mathrm{~mm}$ longae, apice rotundato. Folia glabra; petiolus 4-6 mm longus; lamina ovata, 20-30 mm longa, (9-)14-16 $\mathrm{mm}$ lata, basi acuta ad breviter subattenuata, margine integra, apice subacuta ad subacuminata. Inflorescentia axillaris, unifloris vel trifloris, fortasse quinquefloris, minus quam $10 \mathrm{~mm}$ longa; pedunculus absens vel usque ad $1 \mathrm{~mm}$ longus; pedicellus circa $2 \mathrm{~mm}$ longus, glaber. Caly $x$ 1.3-1.5 $\mathrm{mm}$ longus, pagina externa glabra, pagina interna moderate tomentosa; lobi ovato-deltoidei, $0.6-1 \mathrm{~mm}$ longi, margine breviter fimbriata, apice acuta. Corolla campanulata, 2.5-3.5 mm longa, pagina externa glabra; tubus 0.8-1 mm longus; lobi 2.5-3 mm longi, basaliter glabri, distaliter papillosi. Filamenta staminum anguste ovoidea, circa $1 \mathrm{~mm}$ longa; antherae plus minusve ovatae, $0.5-0.6$ $\mathrm{mm}$ longae, lobis obtusis, apice breviter deltoideo. Pistillum 1.4-2 mm longum, ovario circa $0.5 \mathrm{~mm}$ alto, stylo $0.2-0.6 \mathrm{~mm}$ longo, stigmate ellipsoideo. Capsulae plus minusve globulares ad leviter ellipsoideae, diametro 5-6 $\mathrm{mm}$. Figure 1.

Type: Australia: New South Wales: Lord Howe Island: South-east spur of Mt Lidgbird, above the saddle between Mt Gower and Mt Lidgbird, Conn 3578 \& Hutton, 29 Feb 1992 (holo NSW 253452; iso in MEL).

Scrambling shrub to $1 \mathrm{~m}$ high. Branches slightly compressed laterally on distal internodes; distal internodes with 2 pairs of lateral ridges extending from between the leaf bases to the next more basal node; glabrous; stipules interpetiolar, depressed triangular to collar-like, 1-1.4 mm long, glabrous, distally rounded. Leaves glossy mid-green, glabrous; petiole 4-6 mm long; lamina ovate, 20-30 mm long, (9-)14-16 mm wide [length to width ratio 1.5-1.9]; base acute to shortly subattenuate; margin entire; apex subacute to subacuminate; midrib raised on lower surface, slightly sunken on upper surface, veins indistinct. Inflorescence axillary, 1-3-flowered, possibly to 5-flowered (see note below), less than $10 \mathrm{~mm}$ long; peduncle absent or up to $1 \mathrm{~mm}$ long; pedicels c. $2 \mathrm{~mm}$ long, glabrous; bracts ovate, c. $0.5 \mathrm{~mm}$ long, glabrous, with margin shortly fimbriate. Calyx 1.3-1.5 mm long; outer surface glabrous; inner surface moderately hairy, hairs minute, to c. $0.1 \mathrm{~mm}$ long; lobes ovate-triangular, $0.6-1 \mathrm{~mm}$ long, margin shortly fimbriate, apex acute; veins not distinct. Corolla 5(or 6)-merous, campanulate, 
2.5-3.5 mm long; outer surface glabrous; tube $0.8-1 \mathrm{~mm}$ long, with inner surface glabrous; lobes $2.5-3 \mathrm{~mm}$ long, glabrous basally, papillose distally; margin papillose to shortly fimbriate (hairs $<0.05 \mathrm{~mm}$ long); venation complex, each lobe supplied by one vein which has usually divided in the upper part of the tube to produce 2 lateral branches which ascend into the lobe, with short to long divergent branchlets usually
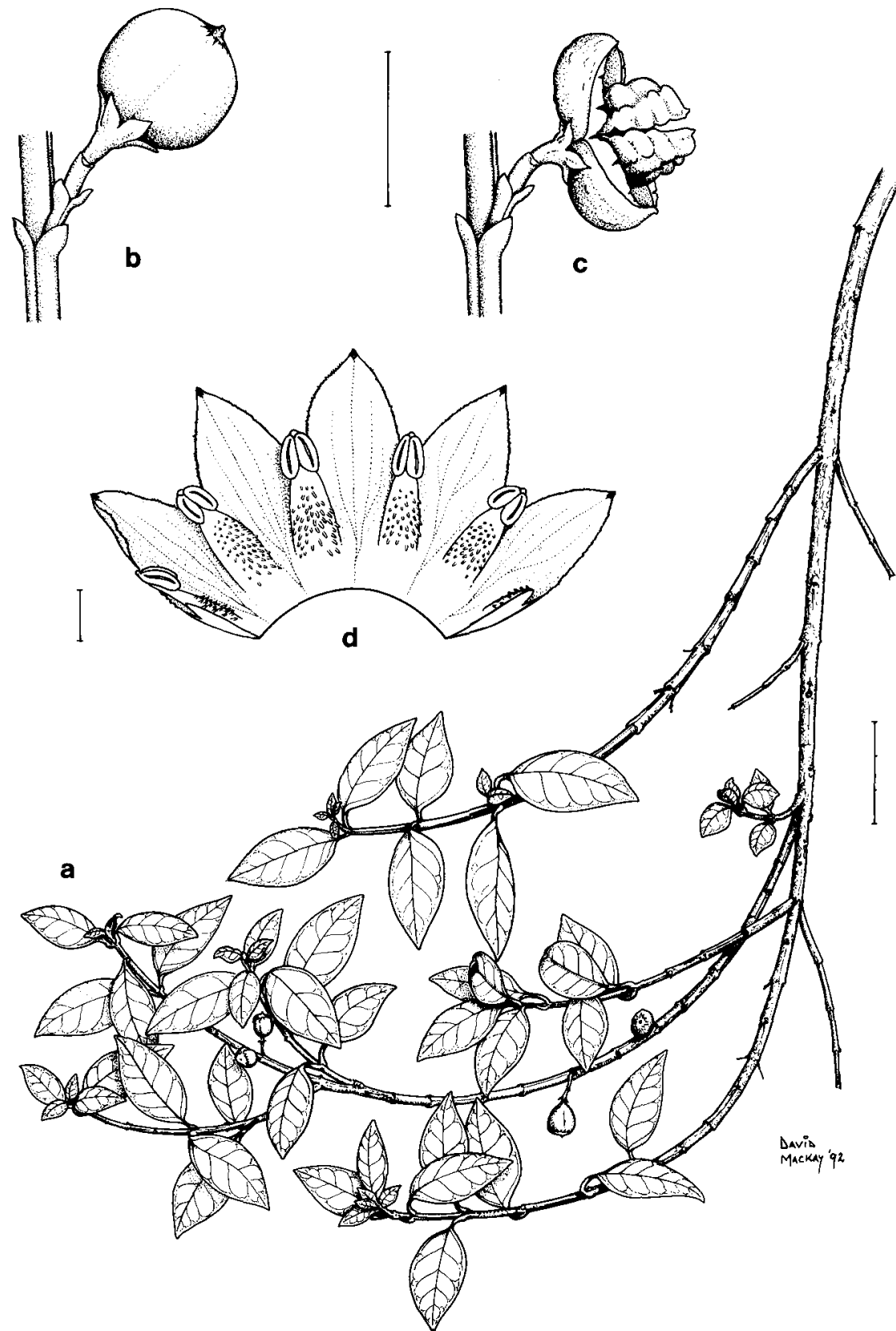

Figure 1. Geniostoma huttonii. a, Branch with capsules; b, detail of capsule and calyx; c, open capsule showing seeds in pulp; $\mathbf{d}$, open flower showing corolla and stamens (all from Conn 3578). Scale bar: $a=3 \mathrm{~cm} ; b \& c=1 \mathrm{~cm} ; d=1 \mathrm{~mm}$. 
present. Staminal filaments narrowly ovoid to slightly ligulate, c. $1 \mathrm{~mm}$ long, c. $0.4 \mathrm{~mm}$ wide, moderately hairy on ventral surface, hairs to $0.1 \mathrm{~mm}$ long, glabrous dorsally; anthers ovate, slightly incurved distally, 0.5-0.6 $\mathrm{mm}$ long, basal lobes obtuse, glabrous, apex sparsely to moderately covered with patent hairs to $0.1 \mathrm{~mm}$ long, connective slightly extended to form a minute triangular, apical appendage c. $0.1 \mathrm{~mm}$ long. Pistil 1.4-2 mm long; ovary glabrous, c. $0.5 \mathrm{~mm}$ long; style $0.2-0.6 \mathrm{~mm}$ long, moderately hairy with patent hairs to $0.1 \mathrm{~mm}$ long; stigma ellipsoid, $0.3-0.7 \mathrm{~mm}$ long. Capsule globular to slightly ellipsoid, 5-6 $\mathrm{mm}$ diameter.

Distribution: Endemic to Lord Howe Island, New South Wales, Australia.

HABIтAT: This species occurs on steep slopes in Metrosideros neroulosa and Westringia viminalis shrub communities, in basalt-derived soils. Altitude $600 \mathrm{~m}$.

Notes: Although the inflorescence is usually uniflorous or triadic, it is either derived from a botryoidal or metabotryoidal inflorescence because of the prophylls and metaxyphylls (together there are usually 2 pairs, rarely 3 pairs).

Geniostoma huttonii is readily distinguished from G. petiolosum, the other species that occurs on the island, by several characters. Geniostoma huttonii has smaller leaves (petiole 4-6 mm long; lamina ovate, 20-30 mm long, (9-)14-16 mm wide) than G. petiolosum (petiole 10-15 $\mathrm{mm}$ long and lamina narrowly ovate-oblong to oblongelliptic, $80-115 \mathrm{~mm}$ long, $20-35 \mathrm{~mm}$ wide). The inflorescence of the former species is few-flowered, probably less than 5-flowered, and less than $10 \mathrm{~mm}$ long, whereas G. petiolosum has a mostly botryoidal or metabotryoidal inflorescence, although sometimes triadic, and (8-)10-20 mm long. Geniostoma huttonii has short peduncles (up to $1 \mathrm{~mm}$ long or absent) and pedicels (c. $2 \mathrm{~mm}$ long), whereas, G. petiolosum has longer peduncles (3-4 mm long) and pedicels (4-6 mm long). The calyx of G. huttonii is 1.3$1.5 \mathrm{~mm}$ long, with inner surface moderately covered with minute hairs, whereas G. petiolosum has a larger glabrous calyx $(2.5-4 \mathrm{~mm}$ long). Geniostoma huttonii is a scrambling shrub (usually less than $1 \mathrm{~m}$ high), whereas G. petiolosum is a small tree (2-5 m high). The flowers of G. huttonii lack an odour, but those of G. petiolosum are very strongly and pungently aromatic.

The affinities of this new species are not clear, but there are strong similarities to G. antherotrichum of New Guinea. Both species lack hairs on the inner surface of the corolla and have similar venation patterns on the corolla lobes. The two species have reduced inflorescences and similar sized leaves (characteristic of G. antherotrichum var. archboldianum, rather than of the typical variety of the latter). However, the short pistil (reduced style) of G. antherotrichum and the unusually thickened staminal filaments of G. huttonii (see Fig. 1d) lessen the likelihood of the two taxa being closely related.

ETYMology: The epithet of this new species honours Mr Ian Hutton whose extensive knowledge of the natural history of Lord Howe Island has increased understanding of many species occurring there. He discovered this new species in a relatively inaccessible part of the island.

Other SPECIMENS ExAmineD: Lord Howe Island: South-east spur of Mt Lidgbird, above the saddle between Mt Gower and Mt Lidgbird, Conn 3575 \& Hutton, 3581, 3582, 29 Feb. 1992 (NSW 253366, 253459 \& 253460, respectively); same locality, Hutton 646, 647, 11 Jan. 1991 (CBG 9105214 \& CBG 9105215, respectively) [the locality of these Hutton collections was incorrectly given as 'above the Nobbin', the actual position of 'The Nobbin' is on the north-western face of Mt Lidgbird]; Hutton 657, 24 Jun. 1991 (CBG 9105219). 


\section{Acknowledgements}

I wish to thank Mr Peter Green (K) and Mr Ian Telford (CBG) who both informed me of the existence of this new species. Mr David Mackay (NSW) provided the illustration. Mr Ian Hutton guided me to the relatively inaccessible population of this species. Without his assistance I probably would not have found the population and I would not have discovered the true meaning of vertigo.

\section{Reference}

Conn, B.J. (1980) A taxonomic revision of Geniostoma subg. Geniostoma (Loganiaceae). Blumea 26: $245-364$.

Manuscript received 23 June 1992

Manuscript accepted 1 December 1992 